\title{
بلاغة القراعات في الحركة الإعرابية وأثرها في التفسير
}

Ahmed ALDYAB ${ }^{1}$

APA: Aldyab, A. (2021). بلاغة القراءات في الحركة الإعرابية و أثرها في التفسير. RumeliDE Dil ve Edebiyat Araştırmaları Dergisi, (24), 936-941. DOI: 10.29000/rumelide.990711.

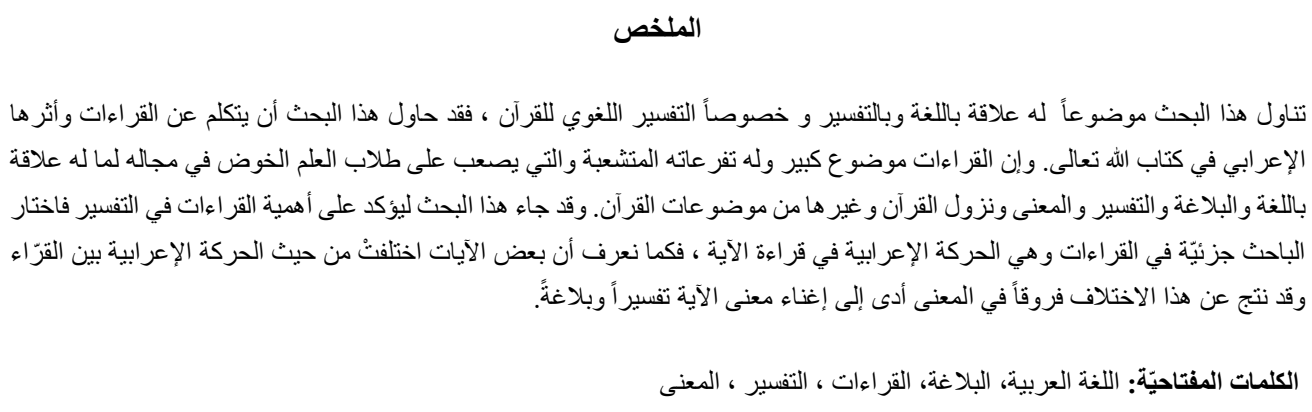

\section{Harekenin irabında kıraat belagati ve tefsire etkisi}

$\ddot{O} \mathbf{z}$

$\mathrm{Bu}$ araştırma, dil ile tefsir arasındaki ililşkiyi inelemekte ve özellikle dil bilimsel tefsir alanından faydalanmaktadır. Çalışma, kıraat ve irab ilişkisini araştırmaktadır. Kıraat konusunun araştırmacıları zorlamasının sebebi, bu ilmin birbirine girmiş teferruatlardan oluşmasının yanında dil, belağat, tefsir, mana, sebeb-i nuzul gibi diğer konularla da ilişkili olmasından kaynaklanmaktadır. $\mathrm{Bu}$ çalışma kıraatın tefsirdeki önemini araştırmak için yapılmıştır, bunu yaparken de özellikle kıraat çeşitlerinden olan 'hareke farklılığının” kur'an tefsirine etkisi incelenmiştir. Okuyucular arasındaki hareke farklılıkları bilinmektedir. Bunun sonucunda mana farklılılığı oluşmaktadır. Mana farklılığı da mana zenginliği sağlamaktadır.

Anahtar kelimeler: Arapça, tefsir, kıraat, belagat, mana

\section{The elequence of readings in the syntactic movement and its impact on the interpretation}

\begin{abstract}
In this studying it has been discussed that there is e relationship between the language and interpretation of Wholly Quran. Especiaaly the language which is used forint erpretation. This sutudying has tried to list the elequence of readings and then the impact of syntactic movementin Quran. The elequence of readings is a wide fieldand it has gotlots of subbranches. This makes the student' jobmore difficult while they a researching about the relation between rhetoricandlanguage. And there alationship between interpretation and them eaning of the versicles Of the Quran. In this studying the importance of the elequence of readings has been discussed and the syntactic movement and its impact on the interpretation has been tried to be illustrated. It has been seen that the researceh ershave different ideas while the yare examining the verse of Quran because of the syntactic
\end{abstract}

Dr. Öğr. Üyesi, Ankara Yıldırım Beyazıt Üniversitesi, İnsan ve Toplum Bilimleri Fakültesi, Doğu Dilleri ve Edebiyatları, Arapça Mütercim Tercümanlık ABD (Ankara, Türkiye), ahmad.adyab@gmail.com, ORCID ID: oooo-0002-9497-9197 [Araştırma makalesi, Makale kayıt tarihi: 30.04.2021-kabul tarihi: 20.09.2021; DOI: 10.29000/rumelide.990711]

Adres | Address

RumeliDE Dil ve Edebiyat Araşturmaları Dergisi Osmanağa Mahallesi, Mürver Çiçeği Sokak, No:14/8 Kadıköy - İSTANBUL / TÜRKIYE 34714 e-posta: editor@rumelide.com tel: +90 $5057958124,+902167730616$

RumeliDE Journal of Language and Literature Studies Osmanağa Mahallesi, Mürver Çiçeği Sokak, No:14/8

Kadıköy - ISTANBUL / TURKEY 34714

e-mail: editor@rumelide.com,

phone: +90 505 7958124, +90 2167730616 
movement. As a result because of these factorseach of them has explained the verses according to their und erstanding. The syntactic movement make their und erstanding different.

Keywords: Arabic language, rhetoric, theelequence of readings, interpretation

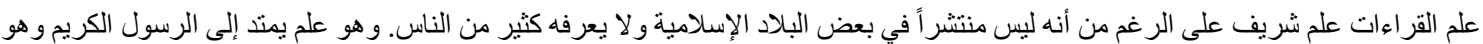

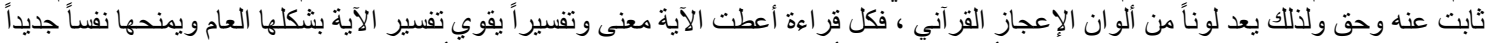

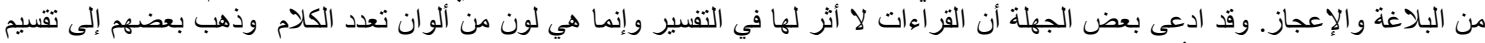

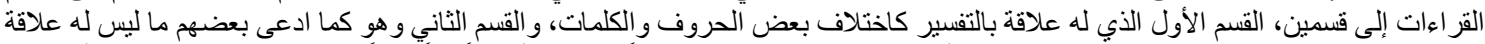

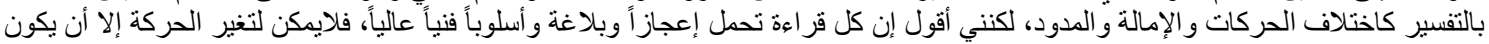

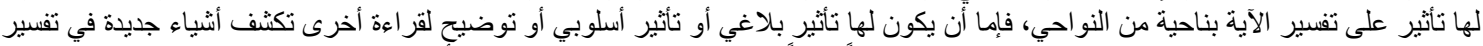

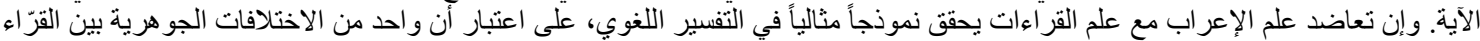

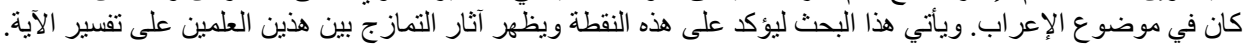

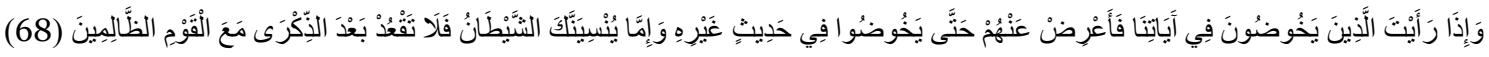

$$
\text { قر قرأ أ أبن عامر بنسينّاك بالتشديد }
$$

نسي:النسيان ترك الإنسان ضبط ما استودع إما لضعف قلبه، و إما من غفلة وإما عن قصد حتى ينحذف عن القلب ذكره، يقال نسيته نسياناً.(الأصفهاني

(1994,512:

$$
\text { المعنى الإجمالي للآية: }
$$

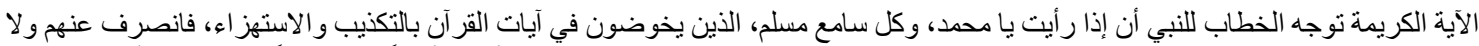

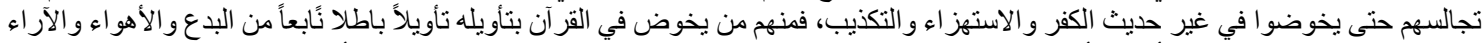

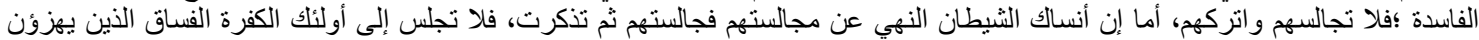

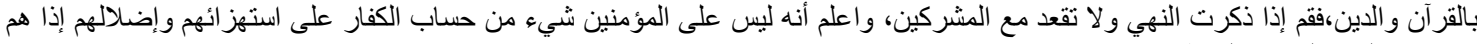
تجنبو هم ولم يجالسو هم(القرطبي:2006:10)

$$
\text { المعنى الكلي للقز اءات: }
$$

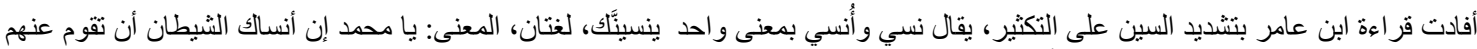

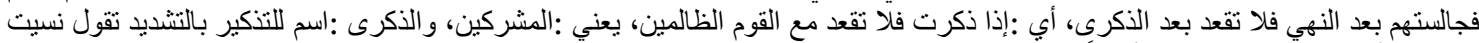

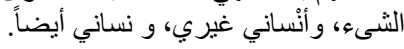

وقرأ ابن عامر ينسينَّك بالتخفيف من أنساني غيري، وحجتهم قوله :فأنساه الثيطان ذكر ربه، ولم يقل فنساه(ابن زنجلة : 1997,256)

$$
\text { الجمع بين القر اءتين }
$$

نجد أن العلاقة بينهما تفسيرية، حيث إن إحداهما تؤكد الأخرى فالتشديد والتخفيف كلاهما ينهى عن مجالسة أهل الاستهزاء بآيات الله والطعن

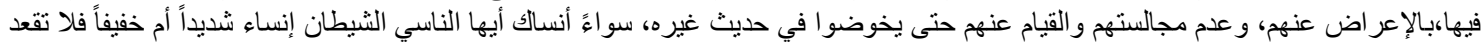

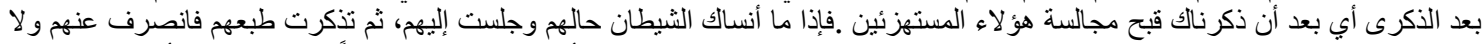

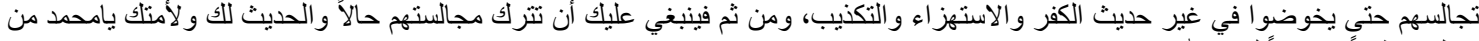
بعدك تعظيماً وتقديساً لكلام الله.

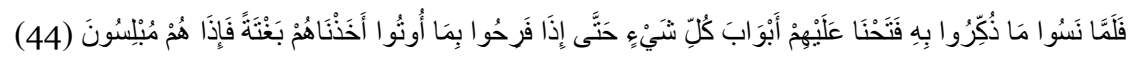

RumeliDE Dil ve Edebiyat Araştırmaları Dergisi Osmanağa Mahallesi, Mürver Çiçeği Sokak, No:14/8 Kadıköy - İSTANBUL / TÜRKIYE 34714 e-posta: editor@rumelide.com tel: +90 $5057958124,+902167730616$
Address

RumeliDE Journal of Language and Literature Studies Osmanağa Mahallesi, Mürver Çiçeği Sokak, No:14/8 Kadıköy - ISTANBUL / TURKEY 34714

e-mail: editor@rumelide.com,

phone: +90 505 7958124, +90 2167730616 
938 / RumeliDE Journal of Language and Literature Studies 2021.24 (September)

The elequence of readings in the syntactic movement and its impact on the interpretation/ A. Aldyab (pp. 936-941)

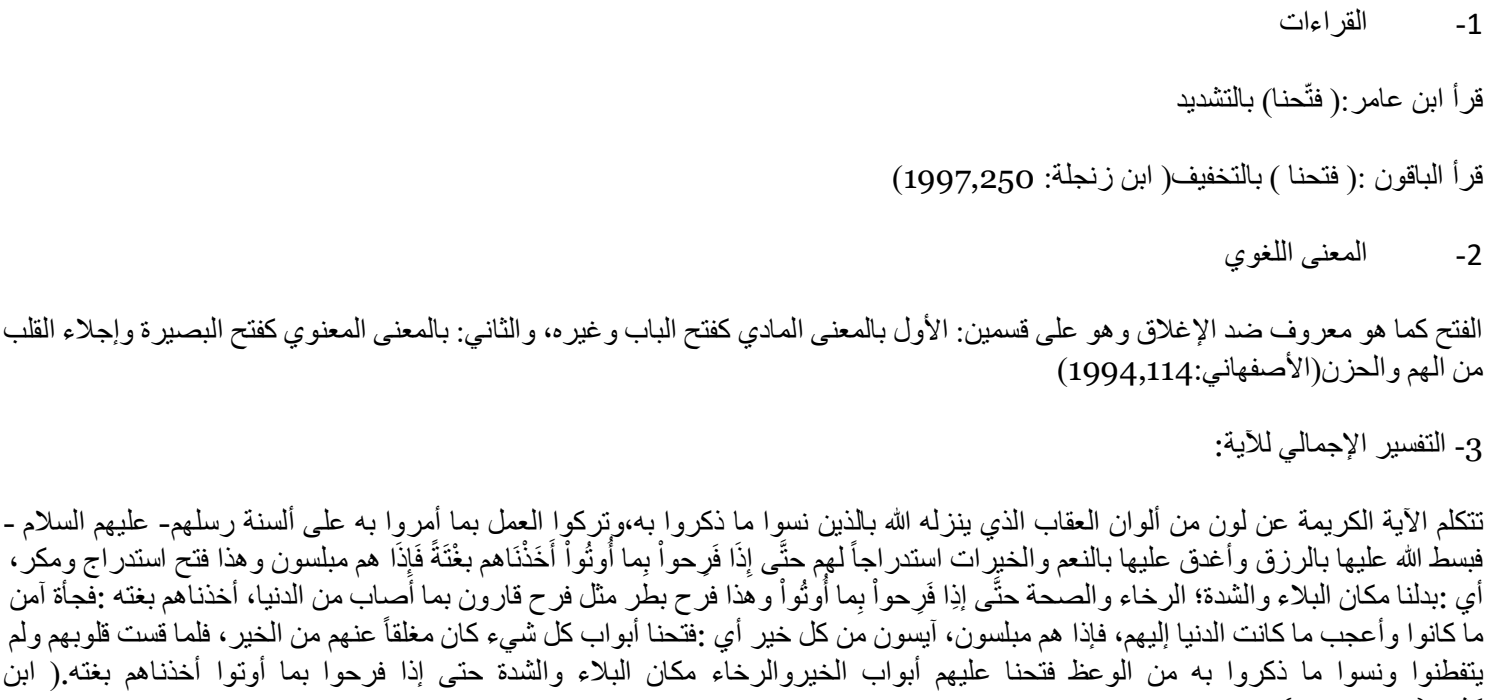

(1999,119):كثير

العلاقة التفسيرية للقر اءات

$-4$

أفادت قر اءة أبي جعفر وابن عامر ( فتّحنا ) بالتشديد التكثير ، والمعنى: أنهم بفرحهم الأعمى الناتج عن بطر النعم والاستخفاف بها وعدم شكر ها فقد

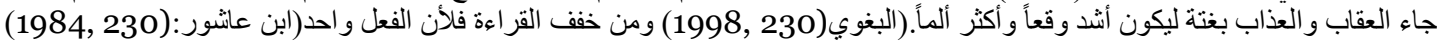

$$
\text { العلاقة بين القراءتين }
$$

العلاقة بين القر اعتين لغوية محضة، فكل قر اءة تؤكد الأخرى وتدعمها، فتشديد القر اعة أفاد التكثير و أخذهم بالعذاب دفعة و احدة وقر اءة التخفيف تفيد الاستدر اج و أخذهم بغتة وفجأة، وبهذا تكون النتيجة واحدة.

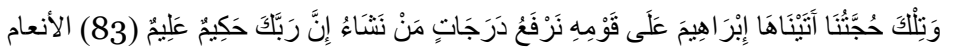
1

قرأ الكوفويون ( نرفع درجاتٍ من نشاء )

قرأ الباقون ( نرفع درجاتٍ من نشاء )(ابن الجزري:(2009, 195)

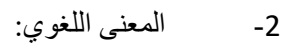

الدرجة هي المنزلة والمرتبة(ابن منظور :2010,266)

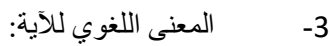

الآية تثبر إلى إعجاز الآيات وكيف أن الله يرفع درجات الصالحين ومن عبده حق العبادة فترتفع درجته إما بالعلم أو إعطائه الحكمة، فالله حكيم بذلك

و عليم بمن بيتحق هذا.(ابن عانشور (1984, 335)

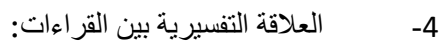

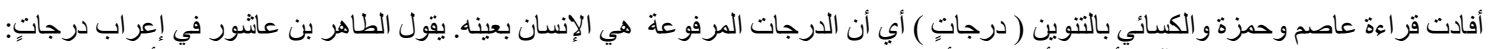

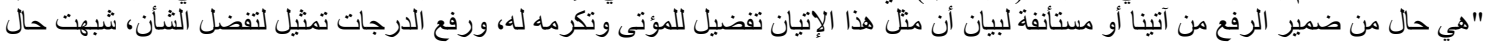

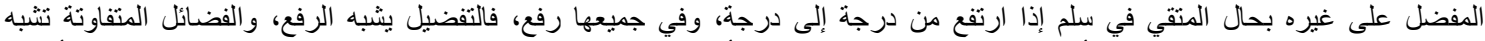

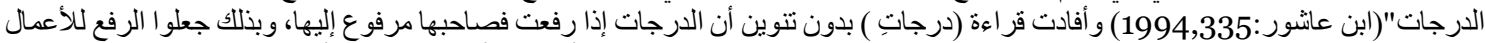

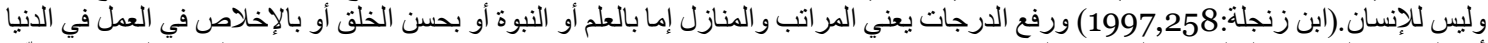

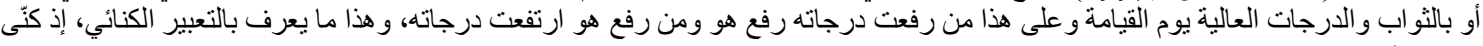
عن رفعة الإنسان ذاته برفع درجاته

Adres | Address

RumeliDE Dil ve Edebiyat Araştırmaları Dergisi $\quad$ RumeliDE Journal of Language and Literature Studies Osmanağa Mahallesi, Mürver Cicçeği Sokak, No:14/8 Osmanağa Mahallesi, Mürver Çiçeği Sokak, No:14/8 Kadıköy - İSTANBUL / TÜRKIYE 34714 Kadıköy - ISTANBUL / TURKEY 34714 e-posta: editor@rumelide.com $\quad$ e-mail: editor@rumelide.com,

tel: +90 505 7958124, +90 216773 o 616 phone: +90 505 7958124, +90 2167730616 
كما هو و اضح أن القر اءتين تؤكد إحداهما الأخرى، فمن رفع هو فقد رُفعت درجاته، و إذا رُفعت درجاته فقد رُفع هو.

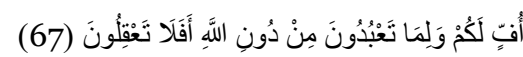

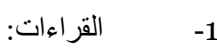
قرأ ابن كثير وابن عامر ويعقوب (أفَّ) ) بفتح الفاء ومن غير تنوين قرأ نافع و أبو جعفر وحفص (أفٍٍ ) بكسر التنوين و التشديد

قرأ الباقون (أفِّ) )بكسر الفاء من غير تنوين(ابن الجزري:2009,306) الاف هو الوسخ شولى اللغوي للقراءات: الأف هو الوسخ حول الظفر أو في الأذن، ويقال عند استقذار الثيء، واستعمل عند التضجر من شيء.(ابن منظور :72010،7) : - $\quad$ التفسير:

يتضجر إبر اهيم من عبادتهم للأصنام ويستنكر ويستقبح ما يفعلون، فهم بذللك يعطلون عقولهم و ومداركهم. يقول أبو السعود: " تضجر منه عليه عليه السلام

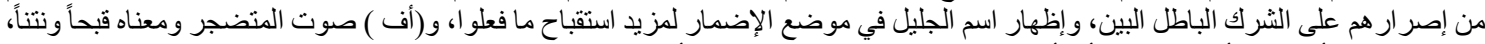
و اللام لبيان المتأفف له ( أفلا تعقلون ) أي ألا تتفكرون فلا تعقلونقبح صنيعكم "(أبو السعود:1992,346)

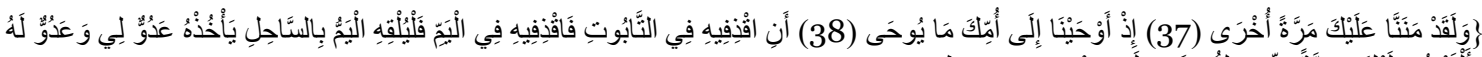

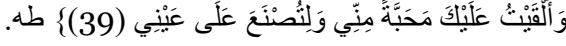

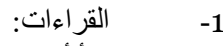

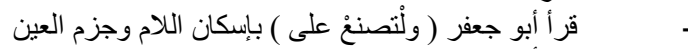

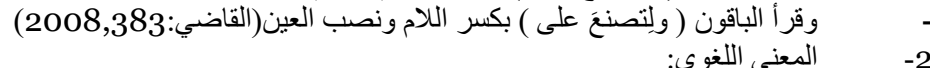

$$
\begin{aligned}
& \text { الصنع إجادة الفعل بأجمل صورة، وكل صنع فعل ويُتخدَم للتربية و التنمية على سبيل المجاز }
\end{aligned}
$$

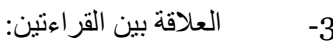

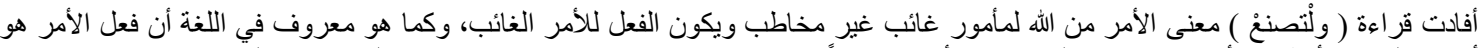
أوجب الصيغ و أقطعها و أقو اها، وحرف الأن العين عندما أصبح ساكناً وجب إدغامه بما بعده، و الإدغام يفيد معنى السر عة في الحديث.

أفادت قراءة ( ولتصنعَ على ) التعليل و السبب و هي متعلقة بألقيت: أي جعلت الناس بحبونك لكي تُصنع كما أريد، أو تكون متعلقة بما بعدها وهو قوله إله

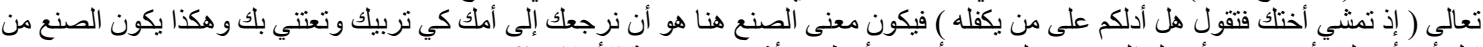

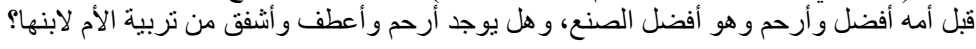

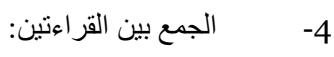

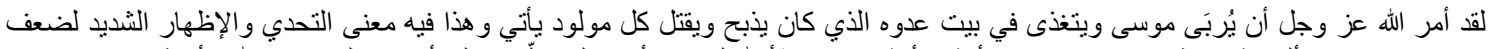

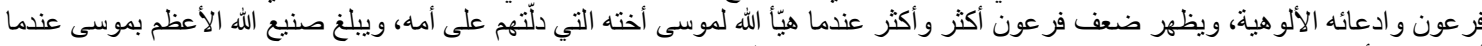

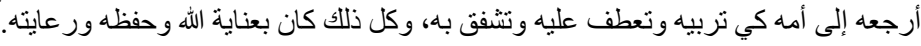

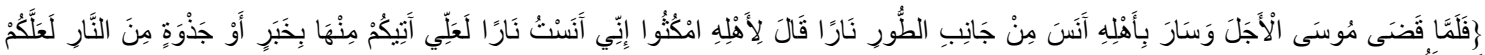
نَصْطَلُونَ (29)

$$
\text { - }
$$

قرأ عاصم ( جَذوة ) بفتح الجيم، وقر أ حمزة وخلف بضم الجيم (جُذوة ) وقر أ الباقون بكسر الجيم (جذوة ).( ابن الجزري:2009,341) Adres $\mid$ Address

RumeliDE Dil ve Edebiyat Araştırmaları Dergisi $\quad$ RumeliDE Journal of Language and Literature Studies Osmană̆a Mahallesi, Mürver Ciçeği Sokak, No:14/8 $\quad$ Osmanağa Mahallesi, Mürver Çiçeği Sokak, No:14/8 Kadıköy - İSTANBUL / TÜRKIYE 34714 Kadıköy - ISTANBUL / TURKEY 34714 e-posta: editor@rumelide.com $\quad$ e-mail: editor@rumelide.com, tel: +90 505 7958124, +90 2167730616 phone: +90 505 7958124, +90 2167730616 
940 / RumeliDE Journal of Language and Literature Studies 2021.24 (September)

The elequence of readings in the syntactic movement and its impact on the interpretation/ A. Aldyab (pp. 936-941)

2

(جذوة) هذه الكلمة بالقر اءات الثناث هي لغات عند العرب ومعناها ما يبقى من الحطب بعد الاشتعال، ومن معانيها الجمر أو عود فيه نار بدون لهب.

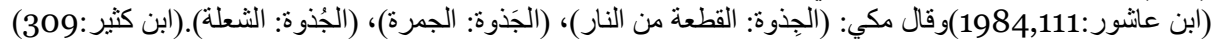

العلاقة بين القراءتين:

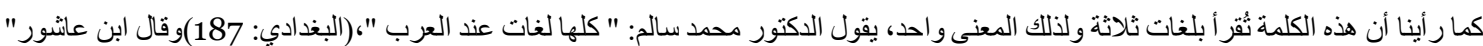

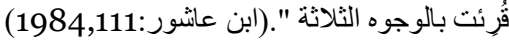

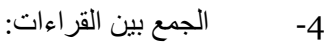
بحسب رأي ابن فارس، فإن اشتعال النار يبدأ بقطعة من النار ثم تصبح شعلة من النار ثم تصبر جمر اً والله أعلم.

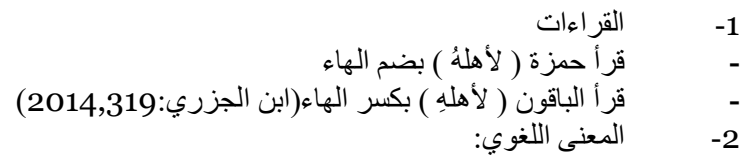

الأهل : أهل الرجل وأهل البيت، يقول الطاهر بن عاشور: الأهل هم الزوج والأولاد.(ابن عاشور:1984,194)

العلاقة بين القراءتين:

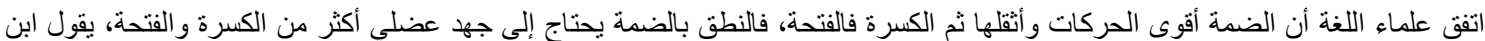

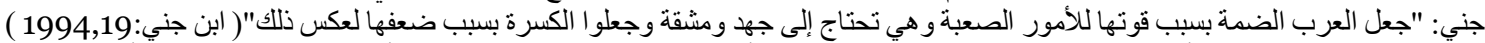

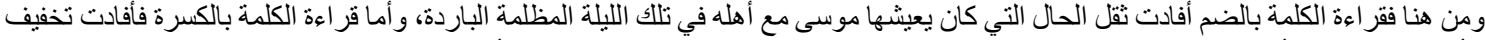

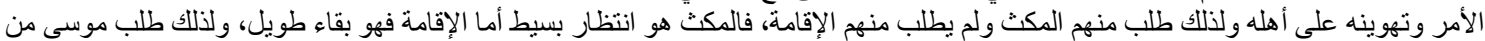

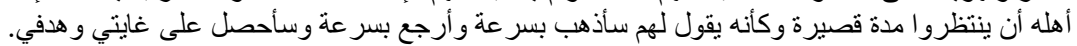

$$
\text { الجمع بين القراءتين: }
$$

على الرغم من ثقل الظرف و الحال التي كان عليها موسى في تللك الليلة إلا أنه تعامل مع أهله بالرحمة والثفقة وحاول أن يخفف الأمر عليه.

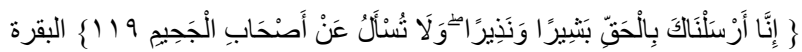

$$
\begin{aligned}
& \text { 1- } \\
& \text { - }
\end{aligned}
$$

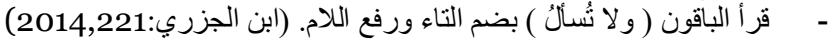

$$
\begin{aligned}
& \text { 2- المعنى اللغوي: } \\
& \text { السؤ ال هو طلب معرفة أو طلب حاجة ما } \\
& \text { 3- - العلاقة بين القر اءتين و الجمع بينهما: }
\end{aligned}
$$

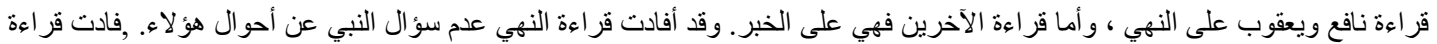

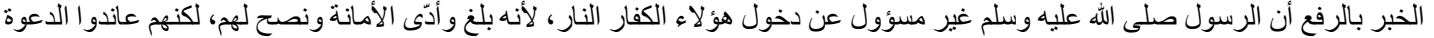
ووققو ا في وجه الإسلام وحاربوه.

لا يجب أن نفهم من النهي أن الله نهى رسوله عن السؤ ال عن هؤلاء الكفار لمجرد النهي فقط، لكن النهي هنا أفاد شدة العذاب و الهول الذي الذي يلاقيه

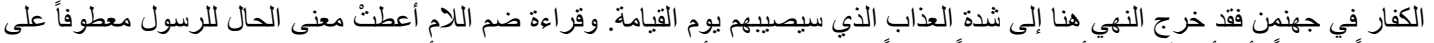

\begin{tabular}{|c|c|}
\hline Adres & Address \\
\hline a $D e r$ & RumeliDE Journal of Language and Literature Studies \\
\hline Mahal & ağa Mahallesi, Mürver Çiçeği Sokak, No:14/8 \\
\hline Kadıköy - İSTANB & Kadıköy - ISTANBUL / TURKEY 34714 \\
\hline $\begin{array}{l}\text { e-posta: editor@rumelide.com } \\
\text { tel: +90 } 5057958124,+90216773 \text { o } 616\end{array}$ & $\begin{array}{l}\text { e-mail: editor@rumelide.com, } \\
\text { phone: +90 505 7958124, +90 } 216773 \text { o } 616\end{array}$ \\
\hline
\end{tabular}

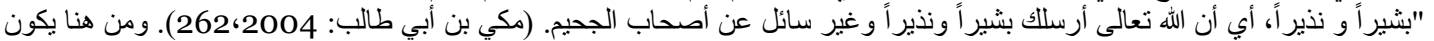

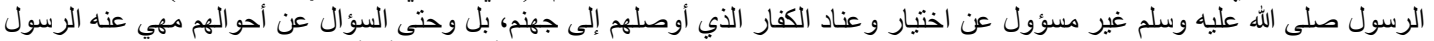

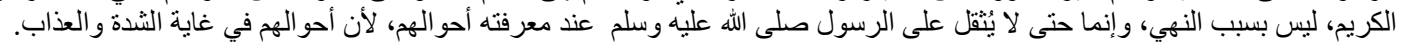

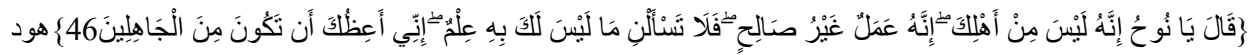




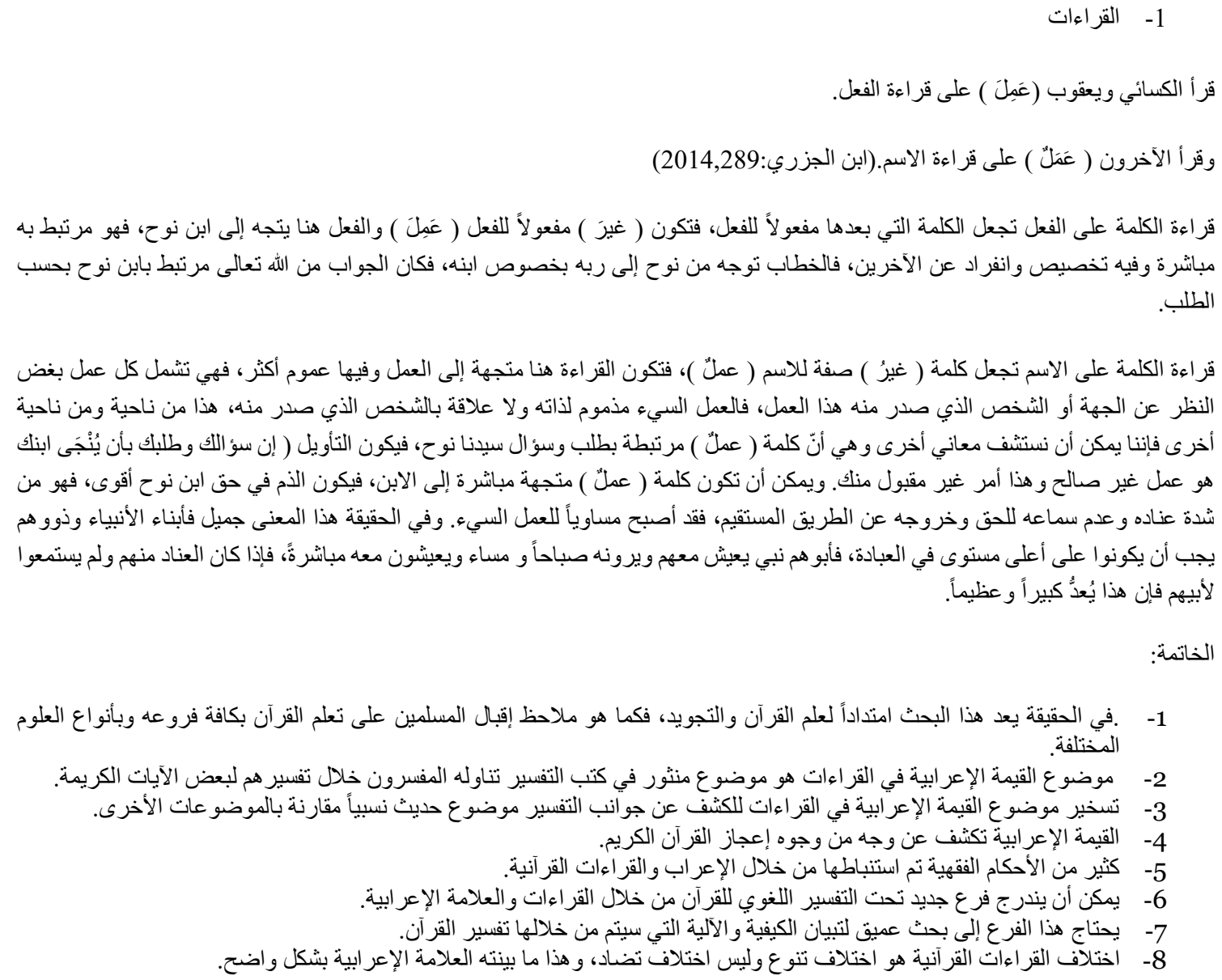

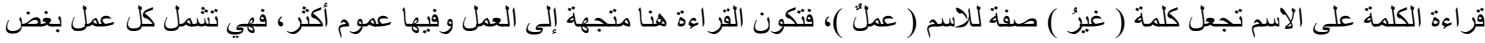

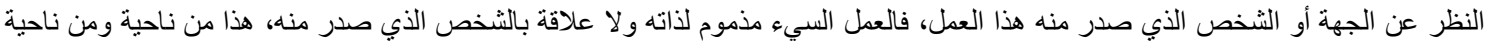

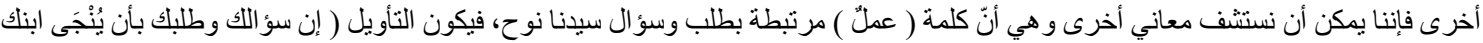

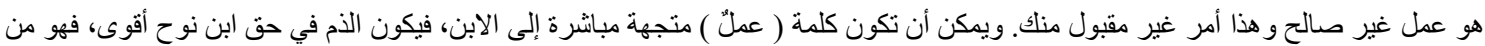

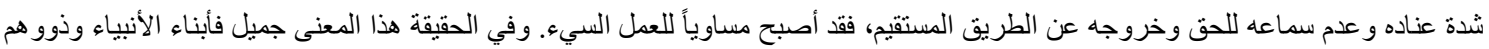

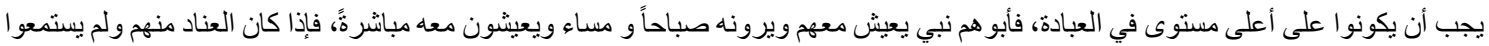
لأبيهم فإن هذا يُعدُّ كبير أ و عظيماً.

1- إفي الحقيقة يعد هذا البحث امتداداً لعلم القرآن والتجويد، فكما هو ملاحظ إقبال المسلمين على تعلم القرآن بكافة فروعه وبأنواع العلوم

2- موضوع القيمة الإعر ابية في القر اءات هو موضوع منثور في كتب التفسير تناوله المفسرون خلال تفسير هم لبعض الآيات الكريمة.

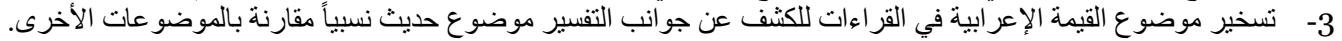

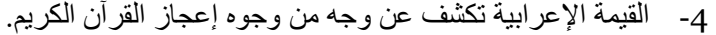

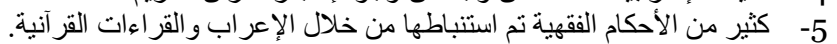

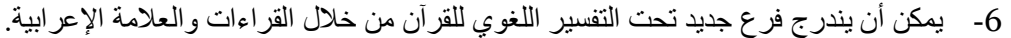

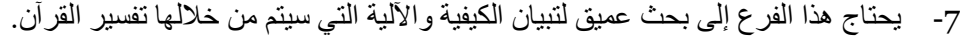

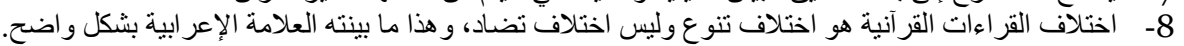

الخاتمة:

\section{Kaynakça}

Ebu's-Suûd, el-İmâdî Muhammed b. Muhammed Mustafa (ö.982/1574). İrşâdü’l-Akli's-Selîm ilâ Mezâya'l-Kitâbi'l-Kerîm. Beyrut: Dâru İhyâi't-Türâsi'l-Arabî. ts.

Isfehânî, Ebu'l-Kâsım Mufaddal Râgıb (1970). Müfredâtü fí ğarîbi'l-Kur'ân, (nşr. Muhammed Ahmed Halefellah), Mektebetü'l Enclo'l-Misriyye.

İbn Âşûr, Muhammed Tahir (1984). et-Tahrir ve’t-Tenvir, Tunus.

İbn Cezerî, Ebü’l-Hayr Şemsüddin Muhammed B. Ali, 2014, En-Neşr Fi'l-Kıraatı'l-Aşr, Daru'l-Fikr, Beyrût.

İbn Cinnî, Ebu'l-Feth Osmân (1986). el-muhteseb fi teybîni vücûhi şevâzzi'l-kurâât ve’lizâhi

İbn Kesir, Ebu'l-Fidâ İsmail b. Amr (1966) Tefsiru'l-Kur'ani'l-Azim, Beyrut.

İbn Manzûr, Ebû'l-Fadl Cemâlu'd-Dîn Muhammed b. Mükerrem b. Alî El-Ensârî (2004). Lisânu'l-Arab, Dâru Sâdır, Beyrût.

İbn Zencele, Ebû Zür‘a (1997). Hüccetü’l-krâ̂ât (tahk. Saîd Afgânî), Beyrut: Risâle.

İbnü'l-Cezerî, Muhammed (2000). en-Neşr fi'l-kurââti'l-'aşr. Thk. Ali Muhammed Dabbâ'. 2 Cilt. Beyrut: ilmiyye.

Kâdî, Abdülfettâh Abdülganî, 2007, Büdûru'z-zâhira fi'l-kurââti'l-'aşri’l-mütevâtire, Dımaşk: Dârü’lBeyrûtî,.

Kurtubî, Muhammed b. Ahmed, 1966, el-Câmi‘u li ahkâmi'l-Kur'ân, Mısır:.

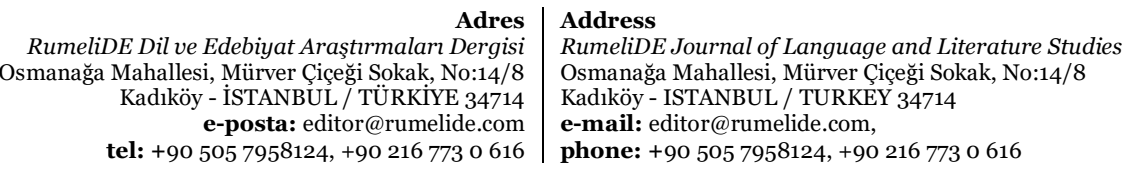

